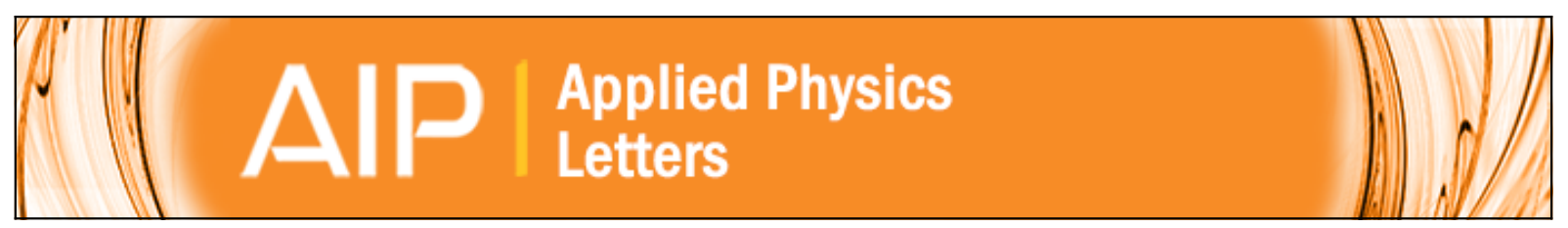

\title{
Correlation between processing conditions of Cu2ZnSn(SxSe1x)4 and modulated surface photovoltage
}

\author{
X. Z. Lin, Th. Dittrich, S. Fengler, M. Ch. Lux-Steiner, and A. Ennaoui
}

Citation: Applied Physics Letters 102, 143903 (2013); doi: 10.1063/1.4801463

View online: http://dx.doi.org/10.1063/1.4801463

View Table of Contents: http://scitation.aip.org/content/aip/journal/apl/102/14?ver=pdfcov

Published by the AIP Publishing

\section{Articles you may be interested in}

Multiwavelength excitation Raman scattering of Cu2ZnSn(SxSe1x)4 (0x1) polycrystalline thin films: Vibrational properties of sulfoselenide solid solutions

Appl. Phys. Lett. 105, 031913 (2014); 10.1063/1.4891333

Employing time-resolved terahertz spectroscopy to analyze carrier dynamics in thin-film Cu2ZnSn(S,Se)4 absorber layers

Appl. Phys. Lett. 104, 253901 (2014); 10.1063/1.4884817

Generalized current-voltage analysis and efficiency limitations in non-ideal solar cells: Case of

Cu2ZnSn(SxSe1x)4 and Cu2Zn(SnyGe1y)(SxSe1x)4

J. Appl. Phys. 115, 234504 (2014); 10.1063/1.4882119

Defect levels in Cu2ZnSn(SxSe1x)4 solar cells probed by current-mode deep level transient spectroscopy Appl. Phys. Lett. 104, 192106 (2014); 10.1063/1.4876925

Lattice positions of Sn in Cu2ZnSnS4 nanoparticles and thin films studied by synchrotron X-ray absorption near edge structure analysis

Appl. Phys. Lett. 102, 221908 (2013); 10.1063/1.4809824

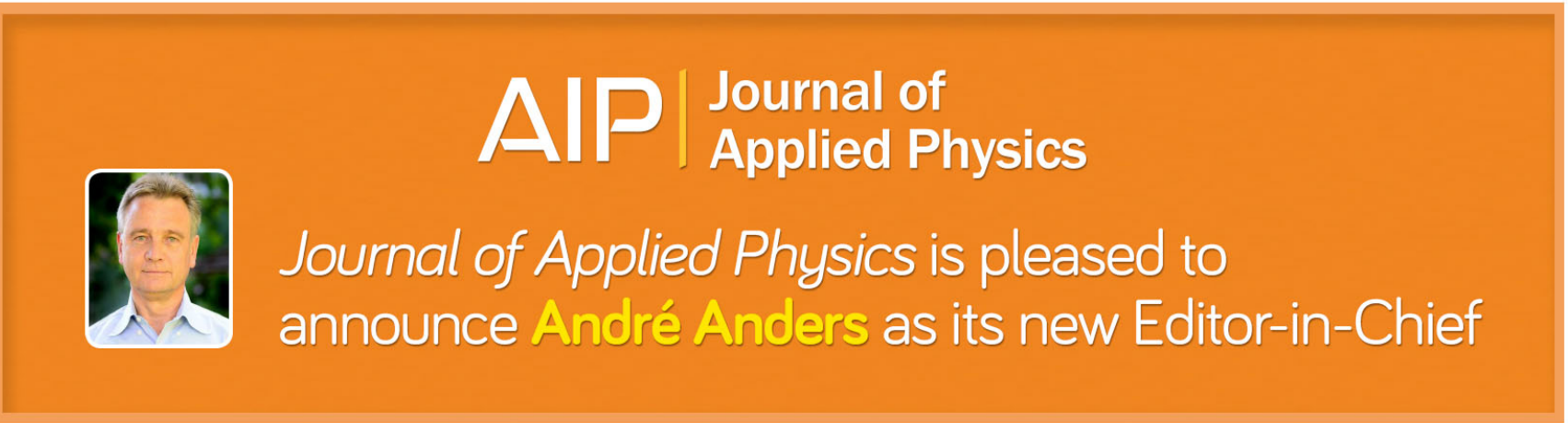




\title{
Correlation between processing conditions of $\mathrm{Cu}_{2} \mathrm{ZnSn}\left(\mathrm{S}_{\mathrm{x}} \mathrm{Se}_{1-\mathrm{x}}\right)_{4}$ and modulated surface photovoltage
}

\author{
X. Z. Lin, ${ }^{\text {a) }}$ Th. Dittrich, S. Fengler, M. Ch. Lux-Steiner, and A. Ennaoui ${ }^{\text {b) }}$ \\ Helmholtz-Zentrum Berlin für Materialien und Energie, Hahn-Meitner-Platz 1, D-14109 Berlin, Germany
}

(Received 27 February 2013; accepted 25 March 2013; published online 11 April 2013)

\begin{abstract}
$\mathrm{Cu}_{2} \mathrm{ZnSn}\left(\mathrm{S}_{\mathrm{x}} \mathrm{Se}_{1-\mathrm{x}}\right)_{4}$ (CZTSSe) layers deposited from multi-component nanoparticle inks were characterized by modulated surface photovoltage (SPV) spectroscopy to investigate the effect of annealing conditions. The SPV signals increased strongly with decreasing sulfur content. Band gaps were obtained in terms of SPV onset energy. A diffusion length of above $1 \mu \mathrm{m}$ was estimated for photo-generated electrons at $\mathrm{x}=0.28$. The band gap increased with increasing $\mathrm{x}$ showing an anomaly in the range of $0.5<\mathrm{x}<1$. The results suggested that an excess of selenium is required for the formation of a photo-active phase reliable for efficient $\mathrm{Cu}_{2} \mathrm{ZnSn}\left(\mathrm{S}_{\mathrm{x}} \mathrm{Se}_{1-\mathrm{x}}\right)_{4}$-based solar cells. (C) 2013 AIP Publishing LLC [http://dx.doi.org/10.1063/1.4801463]
\end{abstract}

As a p-type semiconductor material, $\mathrm{Cu}_{2} \mathrm{ZnSn}\left(\mathrm{S}_{\mathrm{x}} \mathrm{Se}_{1-\mathrm{x}}\right)_{4}$ (CZTSSe) has spurred huge attention across fundamental and applied research due to its potential application as absorber layers in thin solar cells. ${ }^{1-7}$ The direct band gap of $\mathrm{Cu}_{2} \mathrm{ZnSn}\left(\mathrm{S}_{\mathrm{x}} \mathrm{Se}_{1-\mathrm{x}}\right)_{4}$ is tunable in the range between 1.0 and $1.5 \mathrm{eV}$, which is optimal for solar energy conversion. As a further advantage, $\mathrm{Cu}_{2} \mathrm{ZnSn}\left(\mathrm{S}_{\mathrm{x}} \mathrm{Se}_{1-\mathrm{x}}\right)_{4}$ contains only earth abundant elements. However, $\mathrm{Cu}_{2} \mathrm{ZnSn}\left(\mathrm{S}_{\mathrm{x}} \mathrm{Se}_{1-\mathrm{x}}\right)_{4}$ is a quintternary compound with unknown and complicated phase diagram(s) which can contain, for example, as well quaternary and ternary compounds or secondary phases such as $\mathrm{ZnS}$, $\mathrm{Cu}_{\mathrm{x}} \mathrm{S}$, and $\mathrm{Cu}_{2} \mathrm{SnS}_{3}$. Therefore, information about stoichiometry ranges resulting in CZTSSe layers of the kesterite phase with photo-electric properties well suitable for solar energy conversion will be very useful for better understanding of $\mathrm{Cu}_{2} \mathrm{ZnSn}\left(\mathrm{S}_{\mathrm{x}} \mathrm{Se}_{1-\mathrm{x}}\right)_{4}$ and for further development of solar cells based on $\mathrm{Cu}_{2} \mathrm{ZnSn}\left(\mathrm{S}_{\mathrm{x}} \mathrm{Se}_{1-\mathrm{x}}\right)_{4}$.

CZTSSe thin film absorbers can be grown by various approaches such as spin coating of binary chalcogenides or metal salt precursors inks followed by annealing under reactive atmosphere, ${ }^{1,2}$ electrodeposition of metal stacks with subsequential annealing, ${ }^{3,4}$ evaporation, ${ }^{5,6}$ and sputtering. ${ }^{7,8}$ Among various methods, the spin-coating of binary chalcogenide precursors dissolved in hydrazine followed by annealing under Se-atmosphere gives the highest efficiencies of $11.1 \% .^{1}$ In order to fabricate high performance CZTSSebased solar cells, it is crucial to prepare thin film absorbers with pure phase, controlled compositions, and good crystalline quality. For this purpose, technological windows have to be known for each deposition technique. This demands fast characterization methods giving reliable information about photo-active phases without the need for manufacturing complete solar cells, which include charge-selective and Ohmic contacts. As a nondestructive method, surface photovoltage (SPV $)^{9}$ measurements do not require the preparation of Ohmic contacts and allow a very sensitive characterization of photovoltaic absorber materials by detecting separation of photo-generated charge carriers. SPV measurements

\footnotetext{
a)lin.xianzhong@helmholtz-berlin.de

b)ennaoui@helmholtz-berlin.de
}

can provide information about the band structure, parameters of photo-generated charge carriers and about defects below the band gap. In this work, modulated SPV measurements are applied to characterize $\mathrm{Cu}_{2} \mathrm{ZnSn}\left(\mathrm{S}_{\mathrm{x}} \mathrm{Se}_{1-\mathrm{x}}\right)_{4}$ thin films prepared from precursors of $\mathrm{Cu}_{3} \mathrm{SnS}_{4}$ (CTS), $\mathrm{ZnS}$, and $\mathrm{SnS}$ nanoparticles and conditioned by annealing in atmospheres containing sulfur and/or selenium.

Layers of $\mathrm{Cu}_{3} \mathrm{SnS}_{4}$ and/or $\mathrm{ZnS}$ and/or $\mathrm{SnS}$ nanoparticles were deposited on molybdenum coated sodalime glass substrates by spin coating of the nanoparticle inks composed of $\mathrm{Cu}_{3} \mathrm{SnS}_{4}$ and/or $\mathrm{ZnS}$ and/or SnS. CTS, ZnS, and $\mathrm{SnS}$ nanoparticle precursors synthesized by one pot technique. ${ }^{10,11}$ Five different samples were prepared and investigated by SPV. Sample A was prepared from the inks consisting of CTS and ZnS nanoparticles dispersed in 1-hexanethiol by following the procedures reported in Ref. 12. Samples B and C were prepared using the inks composed of CTS, $\mathrm{ZnS}$, and $\mathrm{SnS}$ nanoparticles in 1-hexanethiol with $\mathrm{Cu} /(\mathrm{Zn}+\mathrm{Sn})=0.8$ and $\mathrm{Zn} / \mathrm{Sn}=1.1$ by five successive spin coating at $2000 \mathrm{RPM}$ with pre-heat treatment at $350^{\circ} \mathrm{C}$ for 2 min during the interval of each layer. As-deposited layers were annealed in a quartz tube at $560^{\circ} \mathrm{C}$ for $20 \mathrm{~min}$ under $\mathrm{Ar} / \mathrm{Se} / \mathrm{H}_{2} \mathrm{~S}(5 \%)$ atmosphere. It should be pointed out that during annealing, sample $\mathrm{C}$ was placed near the selenium source. Sample D was prepared from the inks with the same composition by spin coating four successive layers with a first layer treated with $0.004 \mathrm{M}$ ammonium sulfide methanol solution for $30 \mathrm{~s}$. The sample was annealed at $580^{\circ} \mathrm{C}$ in $\mathrm{Ar} / \mathrm{Se}$ atmosphere for $25 \mathrm{~min}$. Sample E was prepared by a two step annealing process with first three layers annealed at $580^{\circ} \mathrm{C}$ in $\mathrm{Ar} / \mathrm{Se}$ vapor atmosphere for $5 \mathrm{~min}$ followed by another two spin coating layers annealed at $580^{\circ} \mathrm{C}$ in $\mathrm{Ar} / \mathrm{Se}$ vapor atmosphere for $25 \mathrm{~min}$. The ink composition for sample $\mathrm{E}$ was $\mathrm{Cu} /(\mathrm{Zn}+\mathrm{Sn})=0.72$ and $\mathrm{Zn} / \mathrm{Sn}=1.1$.

X-ray diffraction (XRD) was used to characterize the structural properties and the stoichiometry of $\mathrm{Cu}_{2} \mathrm{ZnSn}\left(\mathrm{S}_{\mathrm{x}} \mathrm{Se}_{1-\mathrm{x}}\right)_{4}$ thin films. The measurements were carried out in the $2 \theta$ range from $10^{\circ}$ to $90^{\circ}$ on a Bruker D8Advance $\mathrm{X}$-ray diffractometer with $\mathrm{CuK} \alpha$ radiation using a step size of $0.02^{\circ}$ and step time of $4 \mathrm{~s}$. Sample A showed the characteristic diffraction peaks of the CZTS (JCPDS 
26-0575) phase. The diffraction peaks of the other samples containing both $\mathrm{S}$ and $\mathrm{Se}$ ranged between those of the CZTS and CZTSe phases. For example, the most intensive Bragg peak of (112) was located at $28.45^{\circ}, 28.21^{\circ}, 28.05^{\circ}$, $27.65^{\circ}$, and $27.54^{\circ}$ for samples A, B, C, D, and E, respectively. According to Momose et al., ${ }^{8}$ the relationship between $[\mathrm{S}] /([\mathrm{S}]+[\mathrm{Se}])$ and the diffraction angle follows the Vegard's law

$$
2 \theta_{\text {CZTSSe }}=x \cdot 2 \theta_{\text {CZTS }}+(1-x) \cdot 2 \theta_{\text {CZTSe }}+b \cdot x \cdot(1-x),
$$

where $2 \theta$ represents the diffraction angle of the Bragg peak, and $b$ is a bowing parameter. Regarding to Eq. (1) and by using the Bragg peak of (112), the value of $x$ was determined to be $1,0.79,0.67,0.36$, and 0.28 for samples $\mathrm{A}, \mathrm{B}, \mathrm{C}, \mathrm{D}$, and $\mathrm{E}$, respectively.

Modulated SPV measurements were performed in the fixed capacitor arrangement (see insert of Figure 1, see also Ref. 13) at a modulation frequency of $8 \mathrm{~Hz}$. A halogen lamp with a quartz prism monochromator served as light source. The samples were illuminated through the $\mathrm{SnO}_{2}: \mathrm{F}$ electrode deposited on a quartz cylinder and a mica spacer. The SPV signals were detected with a double phase lock-in amplifier. The phase was calibrated with a silicon photodiode.

The in-phase SPV signals of $\mathrm{Cu}_{2} \mathrm{ZnSn}\left(\mathrm{S}_{\mathrm{x}} \mathrm{Se}_{1-\mathrm{x}}\right)_{4}$ layers were negative what is characteristic for a $\mathrm{p}$-type semiconductor in depletion. Figure 1 shows the spectrum of the SPV amplitude for sample E $(x=0.28)$. The band gap of the $\mathrm{Cu}_{2} \mathrm{ZnSn}\left(\mathrm{S}_{0.28} \mathrm{Se}_{0.72}\right)_{4}$ layer can be obtained as the onset energy of the SPV signal and amounts to $E_{\text {on }}=1.054 \mathrm{eV}$. Below $\mathrm{E}_{\mathrm{on}}$, the SPV signals are caused by transitions from defect states in the forbidden band gap.

The diffusion length of minority charge carriers, i.e., of electrons in $\mathrm{Cu}_{2} \mathrm{ZnSn}\left(\mathrm{S}_{\mathrm{x}} \mathrm{Se}_{1-\mathrm{x}}\right)_{4}$ layers $\left(\mathrm{L}_{\mathrm{e}}\right)$, can be obtained from SPV measurements by keeping the SPV signal constant and measuring the light intensity as a function of the reciprocal absorption coefficient $\left(\alpha^{-1}\right) .{ }^{14}$ The absorption spectrum should be known for getting information about $\mathrm{L}_{\mathrm{e}}$. The

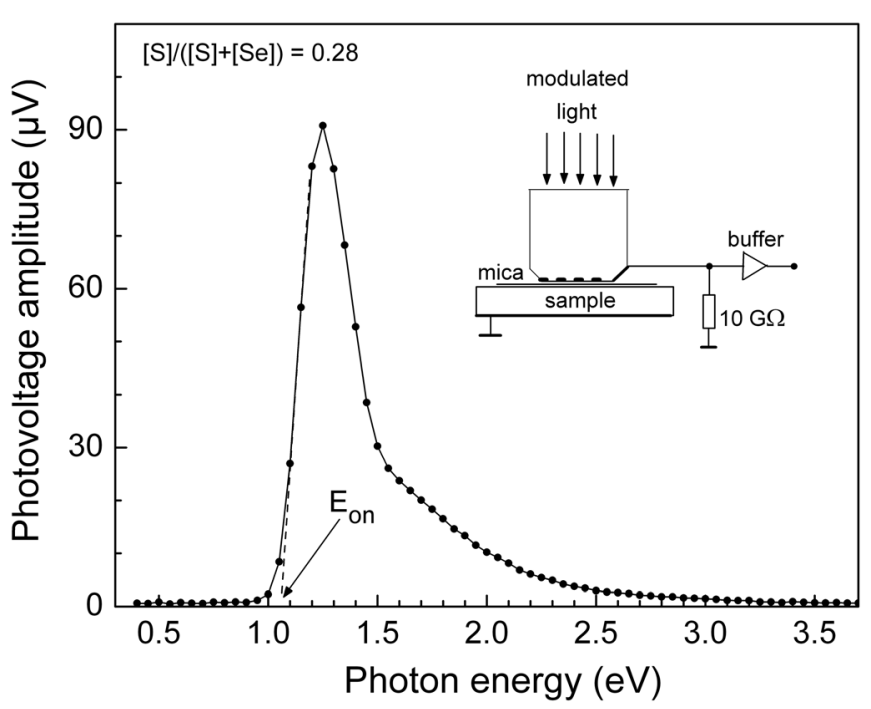

FIG. 1. Spectrum of the surface photovoltage amplitude for the sample $\mathrm{E}$ $(x=0.28)$. The insert shows the measurement set-up. absorption spectra of prepared $\mathrm{Cu}_{2} \mathrm{ZnSn}\left(\mathrm{S}_{\mathrm{x}} \mathrm{Se}_{1-\mathrm{x}}\right)_{4}$ layers cannot be well measured due to uncertainties in phase composition. For SPV analysis, the absorption coefficients were obtained from the absorption spectrum of $\mathrm{Cu}_{2} \mathrm{ZnSnSe}_{4}$ (Ref. 15) shifted to the band gap of $1.054 \mathrm{eV}$. The light intensity was measured with a pyro-electric detector connected with a preamplifier (EMM). The dependence of the light intensity on $\alpha^{-1}$ is depicted in Figure 2 for sample $\mathrm{E}(\mathrm{x}=0.28)$. At larger values of $\alpha^{-1}$, the intensity increases practically linearly with increasing $\alpha^{-1}$ what gives evidence for diffusion limited transport. The diffusion length corresponds to the negative value of the interception point at zero intensity. ${ }^{13}$ It can be seen that $\mathrm{L}_{\mathrm{e}}$ is about $1.2 \mu \mathrm{m}$ for the $\mathrm{Cu}_{2} \mathrm{ZnSn}\left(\mathrm{S}_{\mathrm{x}} \mathrm{Se}_{1-\mathrm{x}}\right)_{4}$ layer with $\mathrm{x}=0.28$. On the other side, the intensity increases strongly with decreasing $\alpha^{-1}$ at low values of $\alpha^{-1}$. This demonstrates the importance of surface recombination.

The spectra of the absolute in-phase SPV signals are given in Figure 3 for samples with $\mathrm{x}=0.28,0.36,0.67$, and 0.79 (E, D, C, B, respectively). The SPV signals increased strongly with increasing selenium content in the spectral range between 1 and about $1.7 \mathrm{eV}$ while the lowest SPV signal was obtained for sample $C(x=0.67)$. Further, there was a qualitative change of the SPV spectra between samples $\mathrm{C}$ $(x=0.67)$ and $\mathrm{D}(\mathrm{x}=0.36)$. Regarding to XRD measurements, the qualitative change can be attributed to the coexistence of phases for sample $\mathrm{C}(\mathrm{x}=0.67)$. The phaseshifted spectrum is shown for the sample with $\mathrm{x}=0.28$. For the given samples, no qualitative differences were found for excitation with photon energies below and above $\mathrm{E}_{\mathrm{on}}$.

The SPV signals were very low for the bare sample A $(\mathrm{x}=1)$, and it was practically impossible to increase the SPV signals during numerous annealing experiments in $\mathrm{H}_{2} \mathrm{~S}$ containing atmosphere. SPV signals of sample A $(x=1)$ increased after depositing a $\mathrm{CdS}$ surface layer. Therefore, sample $\mathrm{A}(\mathrm{x}=1)$ was tested with a CdS surface layer, which was deposited in a chemical bath ${ }^{16}$ (Figure 4). The in-phase SPV signals were positive at photon energies below $1.5 \mathrm{eV}$. The strong decrease of the in-phase SPV signal towards negative values at $1.44 \mathrm{eV}$ corresponds to the onset of

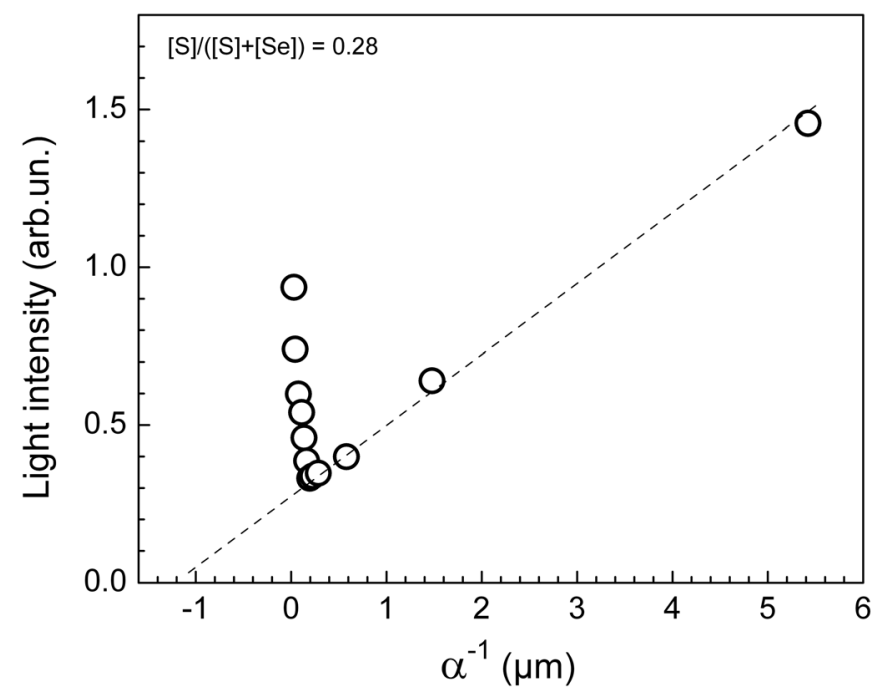

FIG. 2. Dependence of the light intensity (measured with a pyro-detector) on the absorption length obtained from Ref. 15 for sample $\mathrm{E}(\mathrm{x}=0.28)$. 


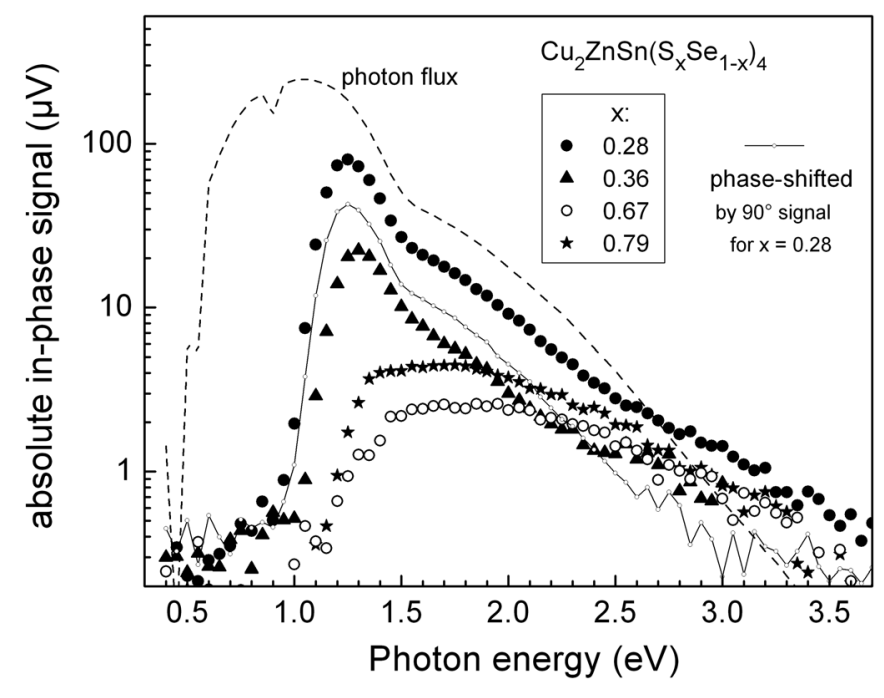

FIG. 3. Spectra of the absolute in-phase surface photovoltage for samples $\mathrm{E}$ $(x=0.28), D(x=0.36), C(x=0.67)$, and $B(x=0.79)$ (filled circles, filled triangles, open circles, stars, respectively). The photon flux spectrum as well as the phase-shifted by $90^{\circ}$ signal for $\mathrm{x}=0.28$ is shown for comparison.

strong absorption in $\mathrm{Cu}_{2} \mathrm{ZnSnS}_{4}$, i.e., to the band gap of $\mathrm{Cu}_{2} \mathrm{ZnSnS}_{4}$. The strong increase of the in-phase SPV signal towards positive values at $2.4 \mathrm{eV}$ corresponds to the band gap of CdS.

The values of $\mathrm{E}_{\text {on }}$ are correlated with $\mathrm{x}$ in Figure 5. The values of $\mathrm{E}_{\mathrm{on}}$ increased with increasing $\mathrm{x}$ while the increase of $E_{o n}$ from sample $B(x=0.79)$ to sample $E(x=1.0)$ was rather steep. Values of $E_{g}$ from literature are shown for comparison $^{8,13,17-19}$ in Figure 5. All values of $E_{\text {on }}$ and $E_{g}$ correlated well with $\mathrm{x}$ up to about 0.4 (region A in Figure 5). The values of $E_{o n}$ and $E_{g}$ scattered over a wide range for $\mathrm{x}$ larger than 0.5 and lower than 1.0 (region B in Figure 5). The values of $E_{o n}$ and $E_{g}$ obtained by electro reflectance of samples with $\mathrm{x}=1.0$ were very similar but underestimated in comparison to $\mathrm{E}_{\mathrm{g}}$ measured by pure optical methods (region $\mathrm{C}$ in Figure 5).

The onset energies measured by SPV seem to be greatly underestimated for samples $\mathrm{B}(\mathrm{x}=0.79)$ and $\mathrm{C}(\mathrm{x}=0.67)$ in relation to $\mathrm{E}_{\mathrm{g}}$ deduced from optical measurements.

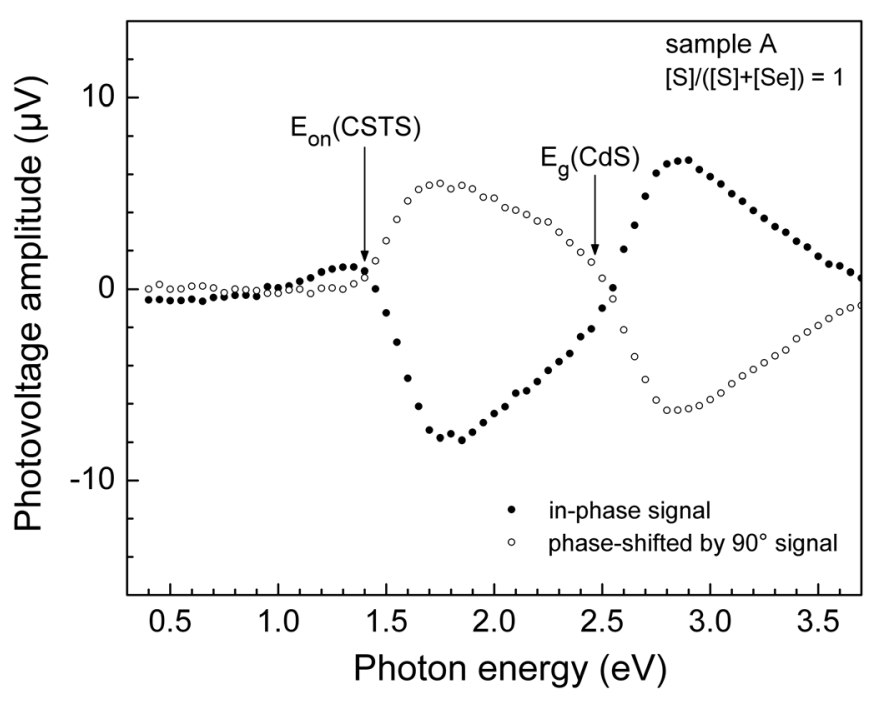

FIG. 4. Spectra of the in-phase and phase-shifted surface photovoltage signals (filled and open circles, respectively) of sample A $(x=1)$ with a CdS surface layer.

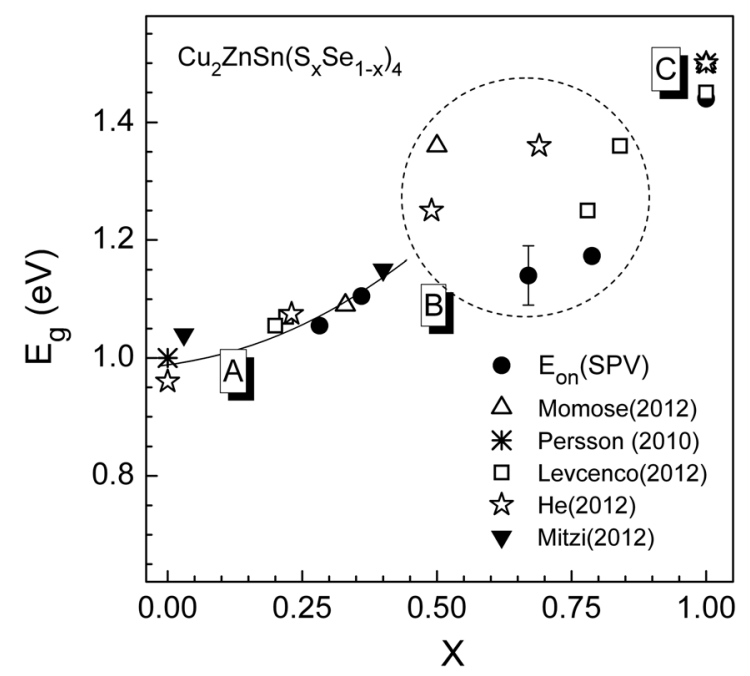

FIG. 5. Dependence of the band gap on the stoichiometry of $\mathrm{Cu}_{2} \mathrm{ZnSn}\left(\mathrm{S}_{\mathrm{x}} \mathrm{Se}_{1-\mathrm{x}}\right)_{4}$ for samples used in this work and for values from the literature. A, B, and $\mathrm{C}$ mark regions of different degree of correlation.

Comparing the optical measurements of the band gap by $\mathrm{He}$ et $a l .{ }^{18}$ and the onset energies measured by SPV, one would expect for samples B and C much lower values for $\mathrm{x}$ (between 0.4 and 0.5 ). SPV measurements are only sensitive to the part of the sample in which charge separation becomes efficient whereas optical and XRD measurements probe the whole sample volume. Therefore, it can be concluded that efficient charge separation in $\mathrm{Cu}_{2} \mathrm{ZnSnSe}_{4}$ is only possible in a phase in which the amount of selenium is larger than the amount of sulfur.

In summary, $\mathrm{Cu}_{2} \mathrm{ZnSn}\left(\mathrm{S}_{\mathrm{x}} \mathrm{Se}_{1-\mathrm{x}}\right)_{4}$ thin films with different values of $x$ have been prepared by spin coating of multicomponent nanoparticle precursors followed by annealing under sulfur or selenium-containing atmosphere. The selenium content of the photo-electrically active phase in $\mathrm{Cu}_{2} \mathrm{ZnSn}\left(\mathrm{S}_{\mathrm{x}} \mathrm{Se}_{1-\mathrm{x}}\right)_{4}$ thin films and the diffusion length are of great importance for the development of solar cells using $\mathrm{Cu}_{2} \mathrm{ZnSn}\left(\mathrm{S}_{\mathrm{x}} \mathrm{Se}_{1-\mathrm{x}}\right)_{4}$ layers as absorbers. Our results implement that a content of selenium larger than the content of sulfur is required for the preparation of $\mathrm{Cu}_{2} \mathrm{ZnSn}\left(\mathrm{S}_{\mathrm{x}} \mathrm{Se}_{1-\mathrm{x}}\right)_{4}$ layers from nanoparticle or hydrazine precursors in order to get efficient charge separation and diffusion of minority charge carriers. This is in accordance with the facts that record solar cells with $\mathrm{Cu}_{2} \mathrm{ZnSn}\left(\mathrm{S}_{\mathrm{x}} \mathrm{Se}_{1-\mathrm{x}}\right)_{4}$ absorbers were obtained for $\mathrm{x}=0.03$ and $\mathrm{x}=0.4$ (Ref. 19) (hydrazine based precursors) and that partial selenization of $\mathrm{Cu}_{2} \mathrm{ZnSnS}_{4}$ nanoparticle layers was needed for achieving a high energy conversion efficiency. ${ }^{20}$

This work was carried out as part of a program supported by the BMBF (Grant 03SF0363B). The authors would like to thank J. Klaer for the preparation of Mo substrates and C. Ferber for the deposition of CdS. One of the authors (X. Z. Lin) gratefully acknowledges the financial support from the Chinese Scholarship Council, HZB and Helmholtz Association.

${ }^{1}$ T. K. Todorov, J. Tang, S. Bag, O. Gunawan, T. Gokmen, Y. Zhu, and D. B. Mitzi, Adv. Energy Mater. 3, 34 (2013).

${ }^{2}$ W. Ki and H. W. Hillhouse, Adv. Energy Mater. 1, 732 (2011). 
${ }^{3}$ S. Ahmed, K. B. Reuter, O. Gunawan, L. Guo, L. T. Romankiw, and H. Deligianni, Adv. Energy Mater. 2, 253 (2012).

${ }^{4}$ A. Ennaoui, M. Lux-Steiner, A. Weber, D. Abou-Ras, I. Kötschau, H.-W. Schock, R. Schurr, A. Hölzing, S. Jost, and R. Hock, Thin Solid Films 517, 2511 (2009).

${ }^{5}$ I. Repins, C. Beall, N. Vora, C. DeHart, D. Kuciauskas, P. Dippo, B. To, J. Mann, W. C. Hsu, A. Goodrich, and R. Noufi, Sol. Energy Mater. Sol. Cells 101, 154 (2012).

${ }^{6}$ B. Shin, Y. Zhu, N. a. Bojarczuk, S. Jay Chey, and S. Guha, Appl. Phys. Lett. 101, 053903 (2012).

${ }^{7}$ H. Katagiri, K. Jimbo, S. Yamada, T. Kamimura, W. S. Maw, T. Fukano, T. Ito, and T. Motohiro, Appl. Phys. Express 1, 041201 (2008).

${ }^{8}$ N. Momose, M. T. Htay, K. Sakurai, S. Iwano, Y. Hashimoto, and K. Ito, Appl. Phys. Express 5, 081201 (2012).

${ }^{9}$ L. Kronik and Y. Shapira, Surf. Sci. Rep. 37, 1 (1999).

${ }^{10}$ X. Lin, A. Steigert, M. C. Lux-Steiner, and A. Ennaoui, RSC Adv. 2, 9798 (2012).

${ }^{11}$ X. Lin, J. Kavalakkatt, M. C. Lux-Steiner, and A. Ennaoui, in 27th EUPVSEC Frankfurt (2012), Vol. 3DV, p. 2794.
${ }^{12}$ X. Lin, J. Kavalakkatt, K. Kornhuber, S. Levcenko M. C. Lux-Steiner, and A. Ennaoui, "Structural and optical properties of $\mathrm{Cu}_{2} \mathrm{ZnSnS}_{4}$ thin film absorbers from $\mathrm{ZnS}$ and $\mathrm{Cu}_{3} \mathrm{SnS}_{4}$ nanoparticle precursors," Thin Solid Films (to be published).

${ }^{13}$ V. Duzhko, V. Timoshenko, F. Koch, and Th. Dittrich, Phys. Rev. B 64, 075204 (2001).

${ }^{14}$ A. M. Goodman, J. Appl. Phys. 32, 2550 (1961).

${ }^{15}$ C. Persson, J. Appl. Phys. 107, 053710 (2010).

${ }^{16}$ B. Johnson, J. Klaer, C.-H. Fischer, and I. Lauermann, Thin Solid Films 520, 2829 (2012).

${ }^{17}$ S. Levcenco, D. Dumcenco, Y. P. Wang, Y. S. Huang, C. H. Ho, E. Arushanov, V. Tezlevan, and K. K. Tiong, Opt. Mater. 34, 1362 (2012).

${ }^{18}$ J. He, L. Sun, S. Chen, Y. Chen, P. Yang, and J. Chu, J. Alloys Compd. 511, 129 (2012).

${ }^{19}$ S. Bag, O. Gunawan, T. Gokmen, Y. Zhu, T. K. Todorov, and D. B. Mitzi, Energy Environ. Sci. 5, 7060 (2012).

${ }^{20}$ Q. Guo, G. M. Ford, W. C. Yang, B. C. Walker, E. A. Stach, H. W. Hillhouse, and R. Agrawal, J. Am. Chem. Soc. 132, 17384 (2010). 